Original research article

\title{
Diterpenes in Coffea canephora
}

\author{
André Luiz Buzzo Mori ${ }^{\mathrm{a}, *}$, Daneysa Lahis Kalschne ${ }^{\mathrm{a}}$, Maria Amélia Gava Ferrão ${ }^{\mathrm{b}}$, \\ Aymbiré Francisco Almeida da Fonsecab ${ }^{\mathrm{b}}$, Romário Gava Ferrão ${ }^{\mathrm{c}}$, Marta de Toledo Benassi ${ }^{\mathrm{a}}$ \\ a Departamento de Ciência de Tecnologia de Alimentos, Universidade Estadual de Londrina, Londrina, Paraná, Brazil \\ ' Embrapa Café, Vitória, Espírito Santo, Brazil \\ ${ }^{\mathrm{c}}$ Instituto Capixaba de Pesquisa, Assistência Técnica e Extensão Rural (Incaper), Vitória, Espírito Santo, Brazil
}

\section{A R T I C L E I N F O}

\section{Article history:}

Received 2 May 2016

Received in revised form 5 August 2016

Accepted 9 August 2016

Available online 10 August 2016

Chemical compounds studied in this article:

Kahweol (PubChem CID: 114778)

Cafestol (PubChem CID: 108052)

16-O-methylcafestol (PubChem CID:

68103163)

\section{Keywords:}

Kahweol

Cafestol

16-O-methylcafestol

UPLC

Conilon

Diamante ES8112

ES8122 'Jequitibá'

Centenária ES8132

Food analysis

Food composition

\begin{abstract}
A B S T R A C T
The presence of diterpenes in coffee has received a great deal of attention in recent years, due to their physiological effects on human health. Some studies related to kahweol and cafestol contents in Coffea arabica are available in the literature; however, information on the impact of genetic variability on the profile of diterpenes in Coffea canephora is scarce. This work evaluates the contents of kahweol, cafestol and 16-O-methylcafestol in 15 genotypes of $C$. canephora. Coffees corresponded to three cultivars Diamante ES8112, ES8122 'Jequitibá' and Centenária ES8132 - with different fruit-ripening seasons (early, medium and late). Coffees were grown at two locations in the state of Espírito Santo, the largest $C$. canephora growing region in Brazil, resulting in 30 samples. Kahweol was absent in $70 \%$ of the samples and the highest content observed was $14.1 \mathrm{mg}^{100 \mathrm{~g}^{-1}}$ in the Jequitibá cultivar. Cafestol was present in all samples and it was the main representative of the diterpene class, with contents varying from $152 \mathrm{mg}$

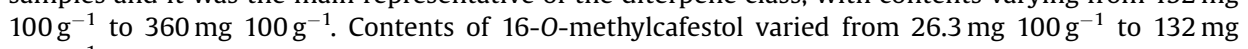
$100 \mathrm{~g}^{-1}$. A significant difference among genotypes was observed, and there was an interaction between genotypes and growing site for the three diterpenes studied.
\end{abstract}

(c) 2016 Elsevier Inc. All rights reserved.

\section{Introduction}

The main compounds of the unsaponifiable matter of coffee lipids are the diterpenes kahweol and cafestol. The consumption of unfiltered coffee brew has been associated with a possible increase in the levels of seric cholesterol and low density lipoproteins; the effects are transient after withdrawal of the diterpenes and are due mainly to the hypercholesterolemic activity of cafestol (CanoMarquina et al., 2013; Higdon and Frei, 2006; Urgert et al., 1995, 1996). However, studies have stressed the beneficial effects of diterpene ingestion on health, due to their anti-carcinogenic, antiinflammatory and antioxidant activities (Cavin et al., 2002; Kim et al., 2006; Gaascht et al., 2015; Higgins et al., 2008; Lee et al., 2007; Muriel and Arauz, 2010; Wang et al., 2012), suggesting that

\footnotetext{
* Corresponding author at: Rodovia Celso Garcia Cid PR 445, km 380, Caixa Postal 10011 Postal Code: 86057 970, Londrina, PR, Brazil.

E-mail address: buzzo.mori@gmail.com (A.L.B. Mori).
}

the moderate consumption of coffee reduces the risk or severity of several diseases (Freedman et al., 2012), being associated with a reduction in mortality rate (Ding et al., 2015).

Amongst the most commercially important coffee species, Coffea canephora stands out for its vigor, being adapted to regions of low altitude and high temperatures and resistant to hydric stress. A coffee brew with low acidity, with more phenolic, spicy, papery and woody aromas and bitter taste, and high astringency and body is produced with $C$. canephora, which is used directly in the production of instant coffee and in blends with Coffea arabica for roasted coffee (Clarke and Macrae, 1985; Williams et al., 1989). Brazil is the second largest grower of $C$. canephora in the world, with a production of 17 million bags of $60 \mathrm{~kg}$ in the 2014/2015 harvest (USDA, 2016), concentrated in the states of Espírito Santo (70\%) and Rondônia (15\%) (CONAB, 2015; MAPA, 2016).

Genetic diversity has contributed to the wide variation in the profile of diterpenes for different coffee species and varieties (Benassi and Dias, 2015; Kitzberger et al., 2013; Speer and Kölling- 
Speer, 2006). Diterpenes have been studied as possible discriminants of the species $C$. canephora and $C$. arabica in roasted coffee blends (De Souza and Benassi, 2012; Speer and Kölling-Speer, 2006). Diterpenes contents in C. arabica are well known, but the literature is highly limited and provides conflicting information for C. canephora. In general, when compared to C. arabica, C. canephora stands out because of its low kahweol content (Campanha et al., 2010; De Souza and Benassi, 2012; Speer and Kölling-Speer, 2006) and the presence of a specific diterpene, 16-O-methylcafestol (Pettitt, 1987; Speer et al., 1991). In a recent review, Benassi and Dias (2015) studied C. canephora from several countries and under different roasting conditions, and found contents of cafestol from

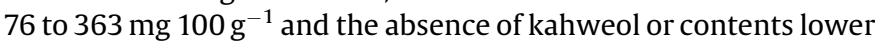

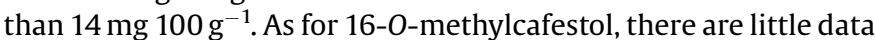

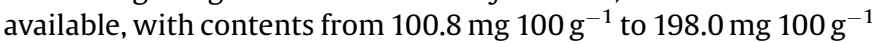
being reported in roasted coffee (Schievano et al., 2014).

In the breeding program of the Instituto Capixaba de Pesquisa, Assistência Técnica e Extensão Rural (Incaper, Espírito Santo, Brazil), a wide variety of $C$. canephora genotypes has being studied for different agronomic traits (Ferrão et al., 2009). Nine cultivars were developed and recommended for the state of Espírito Santo, out of which eight are clonal and one is seed-propagated. Clonal cultivars are formed by groups of compatible clones of $C$. canephora; each cultivar is formed by at least nine clones used in the plantations. Diamante ES8112, ES8122 'Jequitibá', and Centenária ES8132 are examples of clonal cultivars that present different fruit-ripening seasons (early-maturing, medium-maturing and late-maturing, respectively) (Incaper, 2016a,b,c).

Considering the interest in the study of diterpenes, the lack of data on C. canephora matrix, and the importance of Brazil as a grower of this coffee species, the objective of this work was to evaluate the contents of kahweol, cafestol and 16-O-methylcafestol in 15 clones (from now on referred to as genotypes) of three $C$. canephora cultivars - Diamante ES8112, ES8122 'Jequitibá' and Centenária ES8132-grown in two locations.

\section{Materials and methods}

\subsection{Reagents, standards and equipment}

For extraction of diterpenes and preparation of the mobile phase, potassium hydroxide $(\mathrm{KOH})$ analytical grade (F. Maia, São Paulo, Brazil), ethanol 96\% analytical grade (Êxodo Científica, Hortolândia, Brazil), acetonitrile HPLC grade (Fischer Scientific, Bridgewater, NJ) and methyl tert-butyl ether (MTBE) HPLC grade (Acrós Organics, Morris Plains, NJ) were used. Kahweol and cafestol (Axxora, San Diego, CA) of $98 \%$ purity certified by Alexis Biochemicals (Lausen, Switzerland) and 16-O-methylcafestol (Sigma-Aldrich, Saint Louis, MO) of $98.6 \%$ purity were used as standards. The water used for the preparation of standards and solutions was obtained by Elga Purelab Option-Q purification system (Veolia Water Technologies, Saint-Maurice, France). Nylon membranes of $0.22 \mu \mathrm{m}$ were used to filter the mobile phase (Millipore, Billerica, MA) and samples (Whatman, Maidstone, UK).

Chromatographic analyses were performed in an ultra-performance liquid chromatograph Waters Acquity (Waters, Milford, MA) equipped with a flow-through needle injector, a quaternary solvent pumping system, column heater/cooler module and photodiode array detector, controlled by the Empower 3 program.

For color analysis, a Minolta CR-410 colorimeter (Konica Minolta Sensing Inc., Osaka, Japan) was used to obtained the $L^{*}$ (lightness), and the chromatic coordinates $a^{*}$ (red-green component) and $b^{*}$ (yellow-blue component) in the CIE Lab system. The analyses were performed under the conditions of standard illuminant $\mathrm{C}$ and $10^{\circ}$ observer.
For moisture determination, a gravimetric moisture analyzer MB 45 (Ohaus, Barueri, Brazil) with halogen lamp was used. The analysis was performed at $105^{\circ} \mathrm{C}$, to a constant sample weight.

\subsection{Genetic material and preparation}

Fifteen genetic materials (genotypes) from C. canephora originated from the breeding program of INCAPER (Espírito Santo, Brazil) were studied. These genotypes are agronomic divergent and correspond to three clonal cultivars that have distinct fruitripening seasons: Diamante ES8112-early-maturing (genotype 101E, 103E, 105E, 106E, and 108E), ES8122 'Jequitibá' - mediummaturing (genotype $201 \mathrm{M}, 202 \mathrm{M}, 203 \mathrm{M}, 207 \mathrm{M}$, and $209 \mathrm{M}$ ) and Centenária ES8132 - late-maturing (genotype $301 \mathrm{~L}, 302 \mathrm{~L}, 303 \mathrm{~L}$, $306 \mathrm{~L}$, and $307 \mathrm{~L}$ ). Five of the nine genotypes were studied for each cultivar.

Samples were collected from demonstration crops grown under two distinct experimental conditions and at 36 months: a) Experimental Farm of Marilândia - located in the county of Marilândia, in the Northwest of the Espírito Santo state $\left(19^{\circ} 24^{\prime} \mathrm{S}\right.$, $40^{\circ} 31^{\prime} \mathrm{W}$ ), altitude of $104 \mathrm{~m}$, soil of the red-yellow latosol type, dry and hot, with an average annual temperature of $24.2^{\circ} \mathrm{C}$, annual rainfall of $1129 \mathrm{~mm}$; and b) Experimental Farm of Bananal do Norte, located in the county of Cachoeiro do Itapemirim, in the Southern of the Espírito Santo state $\left(20^{\circ} 75^{\prime} \mathrm{S}, 41^{\circ} 29^{\prime} \mathrm{W}\right)$, altitude of $146 \mathrm{~m}$, soil of the red-yellow latosol type, dry and with an average annual temperature of $23.8^{\circ} \mathrm{C}$ and annual rainfall of $1086 \mathrm{~mm}$.

Samples (500 g) were collected in the year 2014, during the harvest from May to July. First, the early maturation genotypes (May) were harvested manually followed by those of medium maturation (June) and late maturation (July). Only cherry stage fruit were collected. Coffee were naturally sun-dried, processed and cleaned. Only non-defective and $16(6.5 \mathrm{~mm})$ sieve-size beans (Brasil, 2003) were selected. The green coffee beans were stored in plastic bags at room temperature until being roasted in October 2014.

Coffees $(100 \mathrm{~g})$ were roasted in a Rod Bel (Rod-Bel, São Paulo, Brazil) gas pilot roaster for $17-29 \mathrm{~min}$, at temperatures from $210^{\circ} \mathrm{C}$ to $230^{\circ} \mathrm{C}$ (Mendes et al., 2001). The diversity in the process was due to differences in size and coffee bean characteristics. The degree of roasting was standardized in order to achieve weight loss of

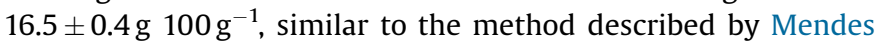
et al. (2001) for an optimal roasting degree for $C$. canephora.

Samples were ground using a Burr bench grinder GVX 2 (Krups, Shanghai, China). Roast coffee was ground at a fine granulometry ( $0 \%$ retained in sieve size $1.18 \mathrm{~mm} ; 70 \%$ retained in sieve size $0.60 \mathrm{~mm}$, and $30 \%$ passing a sieve size $0.60 \mathrm{~mm}$ ), according to ABIC (Brazilian Coffee Roasters Association) (ABIC, 2016). Roast and ground coffees had $L^{*}$ of $25.3 \pm 1.4, a^{*}$ of $8.2 \pm 0.5, b^{*}$ of $10.6 \pm 1.9$,

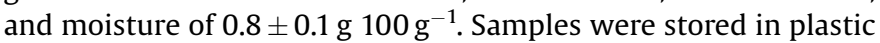
bags and kept at $8^{\circ} \mathrm{C}$ until analysis.

\subsection{Kahweol, cafestol and 16-0-methylcafestol determination}

The extraction was performed as described by Dias et al. (2010). Samples $(0.2000 \mathrm{~g})$ were saponified with $2.0 \mathrm{~mL}$ of potassium hydroxide $(2.5 \mathrm{M})$ in ethanol $(96 \% \mathrm{v} / \mathrm{v})$ at $80^{\circ} \mathrm{C}$ for $1 \mathrm{~h}$. For the extraction of the unsaponifiable matter, $2.0 \mathrm{~mL}$ of distilled water and $2.0 \mathrm{~mL}$ of MTBE were added. After agitation and centrifugation ( $3 \mathrm{~min}$ at $3000 \mathrm{rpm}$ and room temperature), the organic phase was collected. This last stage of the procedure was repeated three times. Distilled water $(2 \mathrm{~mL})$ was added for cleaning and the organic extract was collected and evaporated to dryness in a water bath $\left(70^{\circ} \mathrm{C}\right)$. After resuspension in $4.5 \mathrm{~mL}$ of the mobile phase 
(45:55, v/v, water: acetonitrile), the extract was filtered. Duplicate independent extractions were performed.

The analysis was carried out according to the method developed and validated by Dias et al. (2010) and modified by Wuerges et al. (2016). The analysis was carried out in a Kinetex $2.6 \mu \mathrm{m} \mathrm{C18}(150 \mathrm{~mm} \times 4.6 \mathrm{~mm})$ (Phenomenex, Torrance, CA) column, at $26^{\circ} \mathrm{C}$, with detection at the maximum wavelength of each diterpene: $230 \mathrm{~nm}$ (cafestol and 16-O-methylcafestol) and $290 \mathrm{~nm}$ (kahweol). Isocratic elution of water:acetonitrile (45:55, $\mathrm{v} / \mathrm{v}$ ) at a flow rate of $1.2 \mathrm{~mL} \mathrm{~min}^{-1}$ and an injection volume of $1.4 \mu \mathrm{L}$ were applied. The total chromatographic run time was $7 \mathrm{~min}$. Duplicate injections were done.

Identification was based on retention times and UV spectra. Quantification was carried out by external standardization using 6point analytical curves with triplicate measurements $(r \geq 0.999$, $p<0.001)$ in the concentration range of $2-200 \mu \mathrm{gL}^{-1}$, corresponding to $4.5 \mathrm{mg} 100 \mathrm{~g}^{-1}$, and $450 \mathrm{mg} 100 \mathrm{~g}^{-1}$, respectively.

Considering the analytical curve parameters (ICH, 2005), a detection limit (DL) of $0.5 \mu \mathrm{g} \mathrm{mL}^{-1}$ was obtained for the three compounds and quantification limits (QL) of $1.4 \mu \mathrm{g} \mathrm{mL}^{-1}, 1.6 \mu \mathrm{g}$

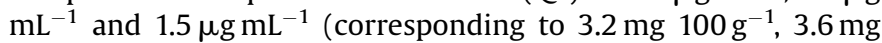
$100 \mathrm{~g}^{-1}$, and $3.4 \mathrm{mg} 100 \mathrm{~g}^{-1}$ ) for kahweol, cafestol and 16-Omethylcafestol, respectively. Diterpene contents were expressed on a dry weight basis $(\mathrm{db})$.

\subsection{Statistical treatment}

To evaluate the effect of growing site and genetic variability, results were submitted to ANOVA and Tukey Test $(p \leq 0.05)$ using the free software SISVAR version 5.6 (SISVAR, 2016). Growing site/ experimental farm (main plot) and genotype (subplot) treatments were considered in a split-plot design. If a significant main $x$ subplot interaction $(p \leq 0.05)$ was observed, the effect of genotype was independently studied for each experimental farm.

\section{Results and discussion}

Tables 1, 2 and 3 show the contents of kahweol, cafestol and 16$O$-methylcafestol, respectively, for 15 different genotypes of $C$. canephora grown at two sites. The total content of diterpenes (the sum of kahweol, cafestol and 16-O-methylcafestol) varied from 191 to $415 \mathrm{mg} 100 \mathrm{~g}^{-1}$. Cafestol was the main representative, with a contribution of $66 \%-90 \%$ of the total diterpenes.

Considering Diamante, Jequitibá and Centenária cultivars, levels of kahweol varied from absent (below LQ of $3.2 \mathrm{mg}$ $100 \mathrm{~g}^{-1}$ ) to $5.3 \mathrm{mg}$ kahweol $100 \mathrm{~g}^{-1}$ (Table 1 ). The average content of cafestol for each cultivar varied from $200 \mathrm{mg} 100 \mathrm{~g}^{-1}$ to $264 \mathrm{mg}$ $100 \mathrm{~g}^{-1}$ (Table 2 ). These values are in agreement with the literature that reports the absence of kahweol or contents below $14 \mathrm{mg}$ of kahweol $\cdot 100 \mathrm{~g}^{-1}$ and from 76 to $363 \mathrm{mg}$ of cafestol $\cdot 100 \mathrm{~g}^{-1}$ for $C$. canephora from several countries and under different roasting conditions (Campanha et al., 2010; De Souza and Benassi, 2012; Lercker et al., 1996; Sridevi et al., 2011).

For kahweol contents, there was a difference $(p<0.001)$ between genotypes but not between growing sites $(p=0.117)$. Considering the average contents for each cultivar, Jequitibá cultivar (medium-maturing) presented higher contents of kahweol; the highest content was observed for genotype $207 \mathrm{M}$

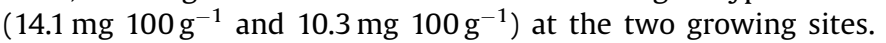
Kahweol was absent in $70 \%$ of the 30 samples analyzed (Table 1 ). There was an interaction between growing site and genotype $(p<0.001)$, showing that kahweol content in each genotype was influenced by the growing site; however, this effect was genotypedependent.

A similar behavior was observed for cafestol: there was a difference $(p<0.001)$ between genotypes but not between growing sites $(p=0.149)$. In general, higher content of cafestol was observed for the Centenária cultivar (late-maturing); the highest values were observed for genotypes 303L and 306L. An interaction between growing site and genotype also occurred for cafestol $(p<0.001)$. Higher contents of cafestol for genotypes 303L

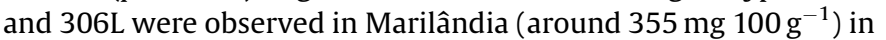
comparison with those obtained for the same genotypes in Bananal

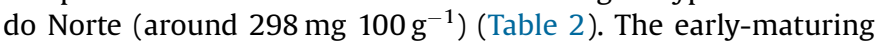
genotypes 101E, 103E and 106E showed the lowest contents of cafestol in Marilândia ( $165 \mathrm{mg} 100 \mathrm{~g}^{-1}, 173 \mathrm{mg} 100 \mathrm{~g}^{-1}$ and $178 \mathrm{mg}$ $100 \mathrm{~g}^{-1}$ ) and genotype 103E showed the lowest content in Bananal

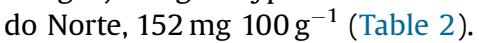

It is difficult to compare our results with the literature due to the limited data available for $C$. canephora; additionally different bases are still used to express diterpene contents. Speer and Kölling-Speer (2001), studying diterpenes in green C. canephora

Table 1

Kahweol content ${ }^{\mathrm{a}}\left(\mathrm{mg} 100 \mathrm{~g}^{-1}\right.$ ) in Coffea canephora genotypes grown at two sites.

\begin{tabular}{|c|c|c|c|}
\hline \multirow[t]{2}{*}{ Cultivar } & \multirow[t]{2}{*}{ Genotypes } & \multicolumn{2}{|c|}{ Growing Site/Experimental Farm } \\
\hline & & Marilândia & Bananal do Norte \\
\hline \multirow[t]{6}{*}{ Diamante (early- maturing) } & $101 \mathrm{E}$ & $0.0^{\mathrm{Be}} \pm 0.0$ & $3.7^{\mathrm{Ae}} \pm 0.0$ \\
\hline & $103 \mathrm{E}$ & $0.0^{\mathrm{Ae}} \pm 0.0$ & $0.0^{\mathrm{Af}} \pm 0.0$ \\
\hline & $105 \mathrm{E}$ & $0.0^{\mathrm{Ae}} \pm 0.0$ & $0.0^{\mathrm{Af}} \pm 0.0$ \\
\hline & $106 \mathrm{E}$ & $0.0^{\mathrm{Ae}} \pm 0.0$ & $0.0^{\mathrm{Af}} \pm 0.0$ \\
\hline & $108 \mathrm{E}$ & $0.0^{\mathrm{Ae}} \pm 0.0$ & $0.0^{\mathrm{Af}} \pm 0.0$ \\
\hline & Mean $^{\mathrm{b}} \pm \mathrm{SD}(\mathrm{CV} \%)$ & $0.0 \pm 0.0(0.0)$ & $0.7 \pm 1.6(228.6)$ \\
\hline \multirow[t]{6}{*}{ Jequitibá (medium- maturing) } & $201 \mathrm{M}$ & $0.0^{\mathrm{Ae}} \pm 0.0$ & $0.0^{\mathrm{Af}} \pm 0.0$ \\
\hline & $202 M$ & $3.8^{\mathrm{Bd}} \pm 0.3$ & $4.7^{\mathrm{Ad}} \pm 0.0$ \\
\hline & $203 M$ & $8.4^{\mathrm{Ab}} \pm 0.1$ & $8.0^{\mathrm{Bb}} \pm 0.3$ \\
\hline & $207 \mathrm{M}$ & $14.1^{\mathrm{Aa}} \pm 0.3$ & $10.3^{\mathrm{Ba}} \pm 0.2$ \\
\hline & $209 M$ & $0.0^{\mathrm{Ae}} \pm 0.0$ & $0.0^{\mathrm{Af}} \pm 0.0$ \\
\hline & Mean $^{\mathrm{b}} \pm \mathrm{SD}(\mathrm{CV} \%)$ & $5.3 \pm 6.0(113.3)$ & $4.6 \pm 4.6(100.0)$ \\
\hline \multirow[t]{6}{*}{ Centenária (late- maturing) } & $301 \mathrm{~L}$ & $0.0^{\mathrm{Ae}} \pm 0.0$ & $0.0^{\mathrm{Af}} \pm 0.0$ \\
\hline & $302 \mathrm{~L}$ & $5.0^{\mathrm{Bc}} \pm 0.1$ & $6.1^{\mathrm{Ac}} \pm 0.3$ \\
\hline & $303 \mathrm{~L}$ & $0.0^{\mathrm{Ae}} \pm 0.0$ & $0.0^{\mathrm{Af}} \pm 0.0$ \\
\hline & $306 \mathrm{~L}$ & $0.0^{\mathrm{Ae}} \pm 0.0$ & $0.0^{\mathrm{Af}} \pm 0.0$ \\
\hline & $307 \mathrm{~L}$ & $0.0^{\mathrm{Ae}} \pm 0.0$ & $0.0^{\mathrm{Af}} \pm 0.0$ \\
\hline & Mean $^{\mathrm{b}} \pm \mathrm{SD}(\mathrm{CV} \%)$ & $1.0 \pm 2.2(220.0)$ & $1.2 \pm 2.7(225.0)$ \\
\hline
\end{tabular}

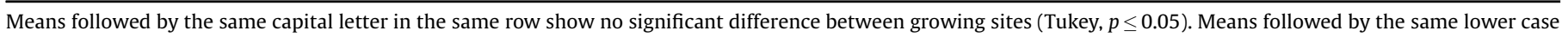
letter in the same column show no significant difference between genotypes (Tukey, $p \leq 0.05$ ).

${ }^{a}$ Mean (duplicates) \pm SD (standard deviation) for each genotype; Zero value corresponds to contents below $\mathrm{QL}^{(3.2 \mathrm{mg}} 100 \mathrm{~g}^{-1}$ ).

b Average content for each cultivar \pm SD (standard deviation) and CV (coefficient of variation) between genotypes of the same cultivar. 
Table 2

Cafestol content ${ }^{\mathrm{a}}\left(\mathrm{mg} 100 \mathrm{~g}^{-1}\right.$ ) in Coffea canephora genotypes grown at two sites.

\begin{tabular}{|c|c|c|c|}
\hline \multirow[t]{2}{*}{ Cultivar } & \multirow[t]{2}{*}{ Genotypes } & \multicolumn{2}{|c|}{ Site/Experimental Farm } \\
\hline & & Marilândia & Bananal do Norte \\
\hline \multirow[t]{6}{*}{ Diamante (early- maturing) } & $101 \mathrm{E}$ & $164.8^{\mathrm{Bg}} \pm 8.9$ & $234.9^{\mathrm{Ae}} \pm 1.4$ \\
\hline & $103 \mathrm{E}$ & $172.7^{\mathrm{Afg}} \pm 2.8$ & $151.7^{\mathrm{Bg}} \pm 1.5$ \\
\hline & $105 \mathrm{E}$ & $230.9^{\mathrm{BC}} \pm 1.4$ & $242.6^{\text {Ade }} \pm 4.6$ \\
\hline & $106 \mathrm{E}$ & $178.1^{\text {Befg }} \pm 0.5$ & $235.5^{\mathrm{Ae}} \pm 3.2$ \\
\hline & $108 \mathrm{E}$ & $254.0^{\mathrm{Ab}} \pm 0.5$ & $252.4^{\text {Acd }} \pm 3.1$ \\
\hline & Mean $^{\mathrm{b}} \pm \mathrm{SD}(\mathrm{CV} \%)$ & $200.1 \pm 39.8(19.9)$ & $223.4 \pm 40.7(18.2)$ \\
\hline \multirow[t]{6}{*}{ Jequitibá (medium- maturing) } & $201 \mathrm{M}$ & $216.7^{\mathrm{Bd}} \pm 0.4$ & $261.4^{\mathrm{Ac}} \pm 4.1$ \\
\hline & $202 \mathrm{M}$ & $231.3^{\mathrm{Ac}} \pm 0.8$ & $233.7^{\mathrm{Ae}} \pm 5.1$ \\
\hline & $203 \mathrm{M}$ & $229.7^{\mathrm{Bcd}} \pm 3.0$ & $245.4^{\text {Ade }} \pm 5.8$ \\
\hline & $207 \mathrm{M}$ & $226.5^{\mathrm{Bcd}} \pm 1.7$ & $239.0^{\text {Ade }} \pm 6.7$ \\
\hline & $209 \mathrm{M}$ & $227.6^{\text {Acd }} \pm 0.8$ & $182.0^{\mathrm{Bf}} \pm 2.7$ \\
\hline & Mean $^{\mathrm{b}} \pm \mathrm{SD}(\mathrm{CV} \%)$ & $226.4 \pm 5.7(2.5)$ & $232.37 \pm 29.9(18.2)$ \\
\hline \multirow[t]{6}{*}{ Centenária (late- maturing) } & $301 \mathrm{~L}$ & $237.0^{\mathrm{Bc}} \pm 1.8$ & $275.6^{\mathrm{Ab}} \pm 4.0$ \\
\hline & $302 \mathrm{~L}$ & $184.7^{\text {Aef }} \pm 1.3$ & $174.9^{\mathrm{Bf}} \pm 6.0$ \\
\hline & $303 \mathrm{~L}$ & $349.5^{\mathrm{Aa}} \pm 0.3$ & $296.3^{\mathrm{Ba}} \pm 0.1$ \\
\hline & $306 \mathrm{~L}$ & $359.7^{\mathrm{Aa}} \pm 1.7$ & $300.0^{\mathrm{Ba}} \pm 2.6$ \\
\hline & $307 \mathrm{~L}$ & $190.3^{\mathrm{Ae}} \pm 3.6$ & $178.4^{\mathrm{Bf}} \pm 6.1$ \\
\hline & Mean $^{\mathrm{b}} \pm \mathrm{SD}(\mathrm{CV} \%)$ & $264.2 \pm 85.0(32.2)$ & $245.0 \pm 63.1(25.8)$ \\
\hline
\end{tabular}

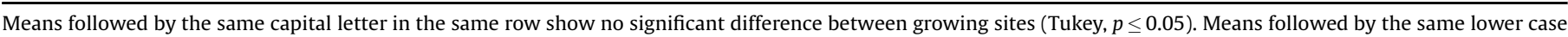
letter in the same column show no significant difference between genotypes (Tukey, $p \leq 0.05$ ).

a Mean (duplicates) \pm SD (standard deviation) for each genotype.

b Average content for each cultivar \pm SD (standard deviation) and CV (coefficient of variation) between genotypes of the same cultivar.

Table 3

Content ${ }^{\mathrm{a}}$ of $16-\mathrm{O}$-methylcafestol $\left(\mathrm{mg} 100 \mathrm{~g}^{-1}\right)$ in Coffea canephora genotypes grown at two sites.

\begin{tabular}{|c|c|c|c|}
\hline \multirow[t]{2}{*}{ Cultivar } & \multirow[t]{2}{*}{ Genotypes } & \multicolumn{2}{|c|}{ Site/Experimental Farm } \\
\hline & & Marilândia & Bananal do Norte \\
\hline \multirow[t]{6}{*}{ Diamante (early- maturing) } & $101 \mathrm{E}$ & $26.3^{\mathrm{Bg}} \pm 0.7$ & $40.8^{\mathrm{Aj}} \pm 0.8$ \\
\hline & $103 \mathrm{E}$ & $35.9^{\mathrm{Bf}} \pm 0.7$ & $42.0^{\mathrm{Aij}} \pm 0.6$ \\
\hline & $105 \mathrm{E}$ & $34.0^{\mathrm{Bf}} \pm 0.2$ & $47.1^{\mathrm{Ahi}} \pm 1.4$ \\
\hline & $106 \mathrm{E}$ & $36.3^{\mathrm{Bf}} \pm 0.4$ & $53.1^{\mathrm{Afg}} \pm 0.1$ \\
\hline & $108 \mathrm{E}$ & $132.1^{\mathrm{Aa}} \pm 2.3$ & $120.8^{\mathrm{Ba}} \pm 0.9$ \\
\hline & Mean $^{\mathrm{b}} \pm \mathrm{SD}(\mathrm{CV} \%)$ & $52.9 \pm 44.5(118.9)$ & $60.8 \pm 33.9(55.8)$ \\
\hline \multirow{6}{*}{ Jequitibá (medium- maturing) } & $201 \mathrm{M}$ & $34.8^{\mathrm{Bf}} \pm 0.4$ & $44.2^{\text {Ahij }} \pm 2.0$ \\
\hline & $202 \mathrm{M}$ & $49.3^{\mathrm{Ae}} \pm 0.2$ & $46.0^{\text {Bhij }} \pm 2.1$ \\
\hline & $203 \mathrm{M}$ & $49.0^{\mathrm{Be}} \pm 1.6$ & $59.7^{\mathrm{Ae}} \pm 1.1$ \\
\hline & $207 \mathrm{M}$ & $68.1^{\mathrm{Bc}} \pm 0.5$ & $91.8^{\mathrm{Ab}} \pm 3.6$ \\
\hline & $209 M$ & $77.7^{\mathrm{Ab}} \pm 0.9$ & $78.7^{\mathrm{Ac}} \pm 0.2$ \\
\hline & $\mathrm{Mean}^{\mathrm{b}} \pm \mathrm{SD}(\mathrm{CV} \%)$ & $55.8 \pm 17.0(30,5)$ & $64.1 \pm 20.7$ \\
\hline \multirow[t]{6}{*}{ Centenária (late- maturing) } & $301 \mathrm{~L}$ & $48.9^{\mathrm{Be}} \pm 0.6$ & $59.6^{\mathrm{Ae}} \pm 1.1$ \\
\hline & $302 \mathrm{~L}$ & $77.2^{\mathrm{Bb}} \pm 0.5$ & $83.3^{\mathrm{Ac}} \pm 1.3$ \\
\hline & $303 \mathrm{~L}$ & $36.8^{\mathrm{Bf}} \pm 0.7$ & $48.7^{\mathrm{Agh}} \pm 1.5$ \\
\hline & $306 \mathrm{~L}$ & $54.9^{\mathrm{Bd}} \pm 0.3$ & $58.1^{\text {Aef }} \pm 2.0$ \\
\hline & $307 \mathrm{~L}$ & $53.9^{\text {Bde }} \pm 0.1$ & $65.1^{\mathrm{Ad}} \pm 3.6$ \\
\hline & $\mathrm{Mean}^{\mathrm{b}} \pm \mathrm{SD}(\mathrm{CV} \%)$ & $54.3 \pm 14.6(26.9)$ & $63.0 \pm 12.8(20.3)$ \\
\hline
\end{tabular}

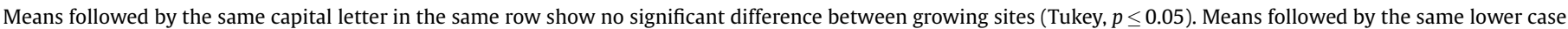
letter in the same column show no significant difference between genotypes (Tukey, $p \leq 0.05$ ).

a Mean (duplicates) \pm SD (standard deviation) for each genotype.

b Average content for each cultivar \pm SD (standard deviation) and CV (coefficient of variation) between genotypes of the same cultivar.

coffees originating from Vietnam, the Ivory Coast, Indonesia, Zaire, Uganda and New Guinea, reported kahweol contents below $10 \mathrm{mg}$ $100 \mathrm{~g}^{-1}$ of unsaponifiable matter and cafestol contents up to $300 \mathrm{mg} 100 \mathrm{~g}^{-1}$ of unsaponifiable matter. Roos et al. (1997) found kahweol at levels below $8 \mathrm{mg} 100 \mathrm{~g}^{-1}$ and cafestol contents of

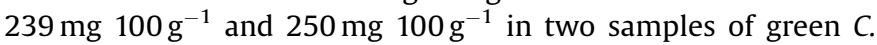
canephora coffee from the Ivory Coast. Kahweol was not detected by De Souza and Benassi (2012) in three roasted Brazilian C. canephora coffees originating from the states of Rondônia and Espírito Santo. Dias et al. (2010), studying C. canephora Apoatã cultivar, did not detect the presence of kahweol in the endosperm of green coffee, and reported cafestol content of $94 \mathrm{mg} 100 \mathrm{~g}^{-1}$. Campanha et al. (2010) reported contents from $163 \mathrm{mg}$ to $275 \mathrm{mg}$ of cafestol $100 \mathrm{~g}^{-1}$ and the absence of kahweol in two C. canephora brazilian coffees, from Rondônia and Espírito Santo states, with different roasting degrees.

Despite the high kahweol values observed for Jequitibá cultivar (Table 1 ) and of cafestol for the Centenária cultivar (Table 2), no effect was observed on the content of this diterpene related to the fruit ripening season (early-maturing, medium-maturing or latematuring), since intra-cultivar variations were more significant. Considering the five genotypes of each cultivar, greater variability was observed in the contents of kahweol, with a coefficient of variation (CV\%) of up to $228.6 \%$, compared to cafestol (CV of up to $32.2 \%$ ) (Tables 1 and 2 ).

The average content of $16-O$-methylcafestol for the Diamante, Jequitibá and Centenária cultivars varied from $52.9 \mathrm{mg} 100 \mathrm{~g}^{-1}$ to

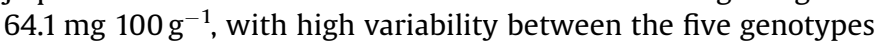
in each cultivar (CV from $20.3 \%$ to $118.9 \%$ ). An effect of the fruit- 
ripening season (early-maturing, medium-maturing or latematuring) on the 16-O-methylcafestol content was not observed (Table 3).

There were significant differences $(p<0.001)$ between genotypes and growing sites $(p<0.029)$ for the contents of $16-O$ methylcafestol. For kahweol and cafestol no systematic effect of growing site was observed.

In general, higher contents of $16-0$-methylcafestol were observed for the coffees grown in Bananal do Norte. The highest contents were observed in genotype $108 \mathrm{E}$ (early-maturing) at the

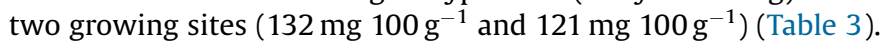
Two early-maturing genotypes (101E, 103E) and one mediummaturing genotype $(201 \mathrm{M})$ stood out due to their lower contents of

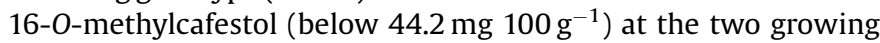
sites. Literature data on 16-O-methylcafestol are scarce and there is no consensus regarding the concentration range. For green $C$.

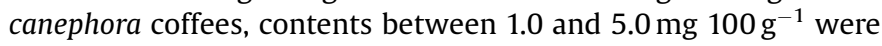
cited by Speer and Kölling-Speer (2006) while Belitz et al. (2009)

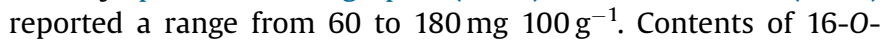

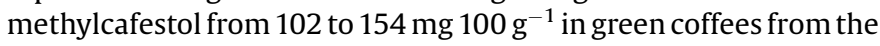
Ivory Coast were reported by Roos et al. (1997). For roasted coffee, Schievano et al. (2014) reported contents from 101 to $198 \mathrm{mg}$ $100 \mathrm{~g}^{-1}$. Pacetti et al. (2012) analyzed diterpenes in four roasted $C$. canephora coffees from India, Vietnam and the Ivory Coast, and reported contents of $16-O$-methylcafestol between $16.2 \mathrm{mg}^{100 \mathrm{~g}^{-1}}$

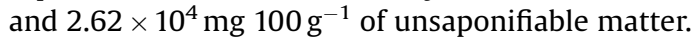

Pettitt (1987) and Speer et al. (1991) described that 16-Ometihylcafestol was present only in $C$. canephora at low concentrations and in the Coffea dewevrei species. As it is thermally stable, this compound could be used as an indicator of the presence of $C$. canephora species in roasted coffee products (Kemsley et al., 1995). In Germany, the quantification of 16-O-methylcafestol is recommended by the norm DIN 10779 (published in 1999) for the evaluation of $C$. canephora coffee percentage in blends with $C$. arabica (Speer and Kölling-Speer, 2006). As Brazil is the second largest producer of this coffee species, the contents of $16-O-$ methylcafestol reported in this study, in which a great number of genotypes were evaluated, can help establish a concentration range of this diterpene in $C$. canephora coffees.

By evaluating the wide range of $16-O$-methylcafestol contents, from 26.3 to $132 \mathrm{mg} 100 \mathrm{~g}^{-1}$, it is suggested that the sole use of this compound content could not be enough to safely estimate the percentage of $C$. canephora in blends with $C$. arabica. A similar observation was made by Schievano et al. (2014). The authors also reported a wide range for $16-O$-methylcafestol content in roasted coffee of three different origins and pointed that such variation is a problem for C. canephora quantification in blends with C. arabica, regardless of the analytical method used.

De Souza and Benassi (2012) propose the use of the relationship kahweol/cafestol as an additional tool to estimate the presence of C. canephora in blends with $C$. arabica. These authors stated that a kahweol/cafestol ratio above 1.00 is indicative of C. arabica and the addition of $C$. canephora coffee should decrease this ratio. In our study, a kahweol/cafestol ratio between 0.00 and 0.06 was obtained; in accordance to De Souza and Benassi (2012) that kahweol/cafestol ratio could be indicative of $C$. canephora. Considering the results, we propose that the combined use of $16-O$-methylcafestol content with kahweol/cafestol ratio could be useful in the discrimination of coffee species. Further studies would verify if these two parameters could indicate with efficiency the addition of $C$. canephora to $C$. arabica in roasted coffee blends.

\section{Conclusions}

The diterpenes profile of $C$. canephora genotypes studied here reinforces the wide variation of kahweol and cafestol contents described in the literature and shows a high variability for 16-Omethylcafestol content. Cafestol represents the largest proportion of diterpenes in C. canephora, being the diterpene with the lowest variability between genotypes of the same cultivar. Kahweol was absent in most genotypes studied.

The fruit-ripening seasons of the cultivars (early-maturing, medium-maturing or late-maturing) do not affect diterpene content, the variation between genotypes of the same cultivar being more relevant. Only contents of 16-O-methylcafestol presented a significant influence of growing site, but an interaction between growing site and genotype was observed for all diterpenes.

\section{Acknowledgements}

The authors are grateful to CNPq (Conselho Nacional de Desenvolvimento Científico e Tecnológico, Brazil) and CAPES (Comissão de Aperfeiçoamento de Pessoal do Nível Superior, Brazil for the scholarships and financial support (CNPq 14/2014 Process: 445757/2014-0) and to IAPAR (Instituto Agronômico do Paraná, Brazil) for the assistance in the roasting process.

\section{References}

ABIC, Associação Brasileira da Indústria de Café, 2016. Norma de qualidade recomendável e Boas Práticas de Fabricação de cafés torrados em grão e cafés torrados e moídos. Revisão no. 27. (retrieved 03.08.16) http://www.abic.com.br/ publique/media/Norma\%20de\%20qualidade.pdf.

Belitz, H.D., Grosch, W., Schieberle, P., 2009. Coffee, tea, cocoa, In: Belitz, H.D., Grosch, W., Schieberle, P. (Eds.), Food Chemistry. 4th ed. Springer, Berlin, Germany, pp. 938-969.

Benassi, M.T., Dias, R.C.E., 2015. Assay of kahweol and cafestol in coffee, In: Preedy, V.R. (Ed.), Coffee in Health and Disease Prevention. 1st ed. Elsevier, London, UK, pp. 995-1005.

Brasil, 2003. Ministério da Agricultura, Pecuária e Abastecimento. Regulamento técnico de identidade e de qualidade para a classificação do café beneficiado e do grão verde. Instrução Normativa $\mathrm{n}^{\circ} 8$ de 11 de junho de 2003. (retrieved 10.04.16) http://www.abic.com.br/publique/media/ CONS_leg_instnormativa08-03.pdf.

CONAB. Companhia Nacional de Abastecimento, 2015. Acompanhamento Da Safra Brasileira: Café. (retrieved 10.04.16) http://www.conab.gov.br/OlalaCMS/ uploads/arquivos/15_12_17_09_02_47_boletim_cafe_dezembro_2015_2.pdf.

Campanha, F.G., Dias, R.C.E., Benassi, M.T., 2010. Discrimination of coffee species using kahweol and cafestol effects of roasting and of defects. Coffee Sci. 5 (1) 87-96.

Cano-Marquina, A., Tarín, J.J., Cano, A., 2013. The impact of coffee on health. Maturitas 75 (1), 7-21.

Cavin, C., Holzhäuser, D., Scharf, G., Constable, A., Huber, W.W., Schilter, B., 2002 Cafestol and kahweol, two coffee specific diterpenes with anticarcinogenic activity. Food Chem. Toxicol. 40 (8), 1155-1163.

Clarke, R.J., Macrae, R., 1985. Chemistry. In: Clarke, R.J., Macrae, R. (Eds.), Coffee, vol 1. Elsevier, London, UK, pp. 83-113.

De Souza, R.M.N., Benassi, M.T., 2012. Discrimination of commercial roasted and ground coffees according to chemical composition. J. Braz. Chem. Soc. 23 (7), 1347-1354.

Dias, R.C.E., Campanha, F.G., Vieira, L.G.E., Ferreira, L.P., Pot, D., Marraccini, P. Benassi, M.T., 2010. Evaluation of kahweol and cafestol in coffee tissues and roasted coffee by a new high-performance liquid chromatography methodology. J. Agric. Food Chem. 58 (1), 88-93.

Ding, M., Satija, A., Bhupathiraju, S.N., Hu, Y., Sun, Q., Han, J., Lopez-Garcia, E., Willett, W., Van Dam, R.M., Hu, F.B., 2015. Association of coffee consumption with total and cause-specific mortality in three large prospective cohorts. Circulation 132 (24), 2305-2315.

Ferrão, M.A.G., Fonseca, A.F.A., Ferrão, R.G., Barbosa, W.M., Souza, E.M.R., 2009. Genetic divergence in conilon coffee revealed by RAPD markers. Crop Breed. Appl. Biotechnol. 9 (1), 67-74.

Freedman, N.D., Park, Y., Abnet, C.C., Hollenbeck, A.R., Sinha, R., 2012. Association of coffee drinking with total and cause-specific mortality. New Engl. J. Med. 366 (20), 1891-1904.

Gaascht, F., Dicato, M., Diederich, M.F., 2015. Coffee provides a natural multitarget pharmacopeia against the hallmarks of cancer. Genes Nutr. 10 (51), 1-17.

Higdon, J.V., Frei, B., 2006. Coffee and health: a review of recent human research. Crit. Rev. Food Sci. Nutr. 46 (2), 101-123.

Higgins, L.G., Cavin, C., Itoh, K., Yamamoto, M., Hayes, J.D., 2008. Induction of cancer chemopreventive enzymes by coffee is mediated by transcription factor Nrf2. Evidence that the coffee-specific diterpenes cafestol and kahweol confer protection against acroleína. Toxicol. Appl. Pharmacol. 226 (3), 328-337.

$\mathrm{ICH}, 2005$. International Conference on Harmonization of Technical Requirements for the Registration of Pharmaceuticals for Human Use. Guidance for Industry, 
Q2B Validation of Analytical Procedures: Methodology. International Conference on Harmonization Secretariat, c/o International Federation of Pharmaceutical Manufacturers and Associations, Geneva, 7-10.

Incaper, 2016. Instituto Capixaba de Pesquisa, Assistência Técnica e Extensão Rural 2015. Diamante ES8112. Documento 219. Nova variedade clonal de café conilon de maturação precoce para o Espírito Santo. (retrieved 03.08.16) http:// biblioteca.incaper.es.gov.br/digital/bitstream/item/786/1/01-FOLDERVARIEDADE-CAFE-DIAMANTE.pdf.

Incaper, 2016. Instituto Capixaba de Pesquisa, Assistência Técnica e Extensão Rural. 2015. ES8122 Jequitibá. Documento 220. Nova variedade clonal de café conilon de maturação intermediária para o Espírito Santo. (retrieved 03.08.16) http:// biblioteca.incaper.es.gov.br/digital/bitstream/item/787/1/02-FOLDERVARIEDADE-CAFE-JEQUITIBA.pdf.

Incaper, 2016. Instituto Capixaba de Pesquisa, Assistência Técnica e Extensão Rural. 2015. Centenária ES8132. Documento 221. Nova variedade clonal de café conilon de maturação tardia para o Espírito Santo. (retrieved 03.08.16) http://biblioteca. incaper.es.gov.br/digital/bitstream/item/785/1/03-FOLDER-VARIEDADE-CAFECENTENARIA.pdf.

Kemsley, E.K., Ruault, S., Wilson, R.H., 1995. Discrimination between Coffea arabica and Coffea canephora variant robusta beans using infrared spectroscopy. Food Chem. 54 (3), 321-326.

Kim, H.G., Kim, J.Y., Hwang, Y.P., Lee, K.J., Lee, K.Y., Kim, D.H., Kim, D.H., Jeong, H.G. 2006. The coffee diterpenes kahweol inhibits tumor necrosis factor-á-induced expression of cell adhesion molecules in human endthelial cells. Toxicol. Appl. Pharmacol. 217 (3), 332-341.

Kitzberger, C.S.G., Scholz, M.B.S., Pereira, L.F.P., Vieira, L.G.E., Sera, T., Silva, J.B.G.D., Benassi, M.T., 2013. Diterpenes in green and roasted coffee of Coffea arabica cultivars growing in the same edapho-climatic conditions. J. Food Compos. Anal. 30 (3), 52-57.

Lee, K.J., Choi, J.H., Jeong, H.G., 2007. Hepatoprotective and antioxidant effects of the coffee diterpenes kahweol and cafestol on carbon tetrachloride-induced liver damage in mice. Food Chem. Toxicol. 45 (11), 2118-2125.

Lercker, G., Caboni, M.F., Bertacco, G., Turchetto, E., Lucci, A., Bortolomeazzi, R., Pagani, E., Frega, N., Bocci, F., 1996. Coffee lipid fraction I. Influence of roasting and decaffeination. Ind. Aliment. 35 (10), 1057-1065.

MAPA, Ministério da Agricultura Pecuária e Abastecimento, 2016. Culturas: Café . (retrieved 10.04.16) http://www.agricultura.gov.br/vegetal/culturas/cafe/saibamais.

Mendes, L.C., Menezes, H.C., Silva, M.A.A.P., 2001. Optimization of the roasting of robusta coffee (C. canephora conillon) using acceptability tests and RSM. Food Qual. Preference 12 (2), 153-162.

Muriel, P., Arauz, J., 2010. Coffee and liver diseases. Fitoterapia 81 (5), 297-305.
Pacetti, D., Boselli, E., Balzano, M., Frega, N.G., 2012. Authentication of italian espresso coffee blends through the GC peak ratio between kahweol and 16-Omethylcafestol. Food Chem. 135 (3), 1569-1574.

Pettitt Jr., B.C., 1987. Identification of the diterpene esters in arabica and canephora coffees. J. Agric. Food Chem. 35 (4), 549-551.

Roos, B., Van Der Weg, G., Urgert, R., Van De Bovenkamp, P., Charrier, A., Katan, M.B., 1997. Levels of cafestol, kahweol, and related diterpenoids in wild species of the coffee plant coffea. J. Agric. Food Chem. 45 (8), 3065-3069.

Sistema De Análise De Variância De Dados Balanceados - Versão 5.6. . (retrieved 10.04.16) http://www.dex.ufla.br/?danielff/programas/sisvar.html.

Schievano, E., Finotello, C., De Angelis, E., Mammi, S., Navarini, L., 2014. Rapid authentication of coffee blends and quantification of 16-O-methylcafestol in roasted coffee beans by nuclear magnetic resonance. J. Agric. Food Chem. 62 (51), 12309-12314.

Speer, K., Kölling-Speer, 2001. Lipids, In: Clarke, R.J., Vitzsthum, O.G. (Eds.), Coffee Recent Developments. 1 ed. Oxford, UK: Blackwell, pp. 33-49.

Speer, K., Kölling-Speer, I., 2006. The lipid fraction of the coffee bean. Braz. J. Plant Physiol. 18 (1), 201-216.

Speer, K., Tewis, R., Montag, A., 1991. A new roasting component in coffee. 14th International Colloquium on the Chemistry of Coffee, ASIC, Paris, pp. 615-621.

Sridevi, V., Giridhar, P., Ravishankar, G.A., 2011. Evaluation of roasting and brewing effect on antinutritional diterpenes-cafestol and kahweol in coffee. Global J. Med. Res. 11 (5), 16-22.

USDA U.S. Department of Agriculture, 2016. Robusta Coffee Production. . (retrieved 10.04.16) http://apps.fas.usda.gov/psdonline/psdReport.aspx? hidReportRetrievalName=Table+03C+Robusta+Coffee +Production\&hidReportRetrievalID=1679\&hidReportRetrievalTemplateID=.

Urgert, R., Van Der Weg, G., Kosmeijer-Schuil, T.G., Van De Bovenkamp, P., Hovenier, R., Katan, M.B., 1995. Levels of the cholesterol-elevating diterpenes cafestol and kahweol in various coffee brews. J. Agric. Food Chem. 43 (8), 2167-2172.

Urgert, R., Meyboom, S., Kuilman, M., Rexwinkel, H., Vissers, M.N., Klerk, M., Katan, M.B., 1996. Comparison of effect of cafetiere and filtered coffee on serum concentrations of liver aminotransferases and lipids: six month randomised controlled trial. Br. Med. J. 313 (30), 1362-1366.

Wang, S., Yoon, Y.C., Sung, M.-J., Hur, H.-J., Park, J.-H., 2012. Antiangiogenic properties of cafestol, a coffee diterpene, in human umbilical vein endothelial cells. Biochem. Biophys. Res. Commun. 421 (3), 567-571.

Williams, A.A., Faria-Morales, A., Kari, P., 1989. Sensory and analytical examination of groud and cup coffee with particular reference to bean maturity. 13th Colloque, Paipa, ASIC, Paipa, pp. 83-106.

Wuerges, K.L., Santos, A.C.F., Mori, A.L.B., Benassi, M.T., 2016. Contents of diterpenes in espresso coffee brews prepared from commercial capsules. Coffee Sci. 11 (2), 276-284. 